\title{
The link between poverty And malnutrition: A South African PERSPECTIVE
}

Author:

Hester (Esté) H. Vorster ${ }^{1}$

\section{Affiliation:}

${ }^{1}$ Faculty of Health

Sciences, North-West

University, South Africa

\section{Correspondence to:}

Esté Vorster

email:

este.vorster@nwu.ac.za

\section{Postal address:}

North-West University,

Private Bag X6001,

Potchefstroom 2520,

South Africa

\section{Keywords:}

double burden of nutrition-related disease; foetal programming; poverty; human capital; obesity; overweight; over-nutrition; stunting; under-nutrition

\section{Dates:}

Received: 22 May 2009

Accepted: 10 Feb. 2010

Published: 18 Aug. 2010

How to cite this article: Vorster, H.H., 'The link between poverty and malnutrition: A South African perspective', Health SA Gesondheid 15(1), Art \#435, 6 pages. DOI: 10.4102/hsag.v15i1.435

This article is available at: http:/ / www.hsag.co.za
(C) 2010. The Authors. Licensee: OpenJournals Publishing. This work is licensed under the Creative Commons Attribution License.

\section{ABSTRACT}

In this article, a brief review of the nutritional problems in South Africa, as well as the intergenerational, vicious cycle of poverty and malnutrition, are used to argue for the necessity of including a nutrition intervention component in poverty-alleviation programmes. It is concluded that this cycle can be broken by improving the nutritional status of women in their productive years, whereby foetal malnutrition, arrested mental development and physical stunting in children, adolescents and adults can be prevented. The result will be an improvement in human capital, health and productivity with the ultimate aim of escaping poverty as suggested by the seven principles of Solomons (2005).

\section{OPSOMMING}

In hierdie artikel word 'n kort oorsig van die voedingsprobleme in Suid-Afrika sowel as die noodlottige siklus van wanvoeding en armoede wat oor generasies strek, gebruik om aan te voer dat dit noodsaaklik is om ' $n$ voedingsintervensie-komponent in programme gemik op die verligting van armoede in te sluit. Daar word tot die gevolgtrekking gekom dat die siklus gebreek kan word as die voedingstatus van vroue in hulle voortplantingsjare verbeter word. Hierdie verbetering sal fetale wanvoeding, sowel as belemmerde groei en kognitiewe ontwikkeling van kinders, adolessente en volwassenes voorkom. Die gevolg sal 'n verbetering van menskapitaal, verbeterde gesondheid en verhoogde produktiwiteit wees, met die uiteindelike doel om armoede te ontsnap soos voorgestel deur die sewe beginsels van Solomons (2005).

\section{INTRODUCTION}

Amartya Sen indicated in his Nobel lecture on 08 December 1998 (Sen 1998:194) why it is so important to define poverty not only in economic terms, but also as a serious deprivation of the capability to lead a minimally acceptable life. He mentioned that poverty is characterised by a lack of opportunities, low personal income and other physical and environmental factors, such as the unavailability and costs of medical care and other facilities. This evolution and broadening of the definition of poverty to include economic as well as social, political, governance-related, educational, opportunities, capabilities and freedom dimensions has led to an increased awareness of the relationship between poverty, malnutrition and health and a focus on the role of food and nutrition security in the alleviation of poverty. The first Millennium Development Goal (Food and Agriculture Organization 2001b), 'Eradication of poverty and hunger', appropriately acknowledges this relationship by stating that poverty and hunger should be addressed simultaneously. To reach this goal, it is important that food insecurity be addressed in development programmes. Food security is defined by the Food and Agriculture Organization of the United Nations as 'access by all people at all times to the food needed for a healthy life' (Food and Agriculture Organization 1997). This definition implies the ready availability of nutritionally adequate and safe foods and an assured ability to acquire acceptable foods in socially acceptable ways.

For many years now, nutritionists have understood the fundamental role of nutrition throughout the lifecycle for the sustained development of human capital (Garza 2002). There is now a firm evidence base for a statement made by Alan Berg in 1973: '[m]alnutrition adversely affects mental development, physical development, productivity, the span of working years - all of which significantly influence the economic potential of man' (Berg 1973:5).

Nutritionists are also aware of the complex inter-relationship between the poverty-related causes and consequences of malnutrition. The conceptual framework of the United Nations Children's Fund (UNICEF 1990), which has been used for decades to analyse malnutrition, includes immediate causes (inadequate dietary intake; lack of care; and disease), underlying causes (inadequate access to food, care for mothers and children and health services; and an unhealthy environment) as well as the basic causes (inadequate education, formal and non-formal institutions, political and ideological superstructures and economic structures and a lack of potential resources). These immediate, underlying and basic causes are now all recognised and defined as dimensions of poverty. Unfortunately, this perception has not always led to an inclusion of an 'eradication of malnutrition' component in poverty-alleviation programmes. This may be a major reason why so many programmes that address poverty, especially in sub-Saharan Africa, are not reaching their goals.

\section{OBJECTIVES}

The objectives of this article are firstly to briefly highlight the nutritional situation in South Africa to show that it is an outcome of the link between poverty and malnutrition and secondly to show how the different dimensions of poverty are both causes and consequences of malnutrition that explain the intergenerational, vicious cycle between poverty and malnutrition. The focus is on the consequences of foetal and childhood malnutrition, using the 'early origin of disease hypothesis' of Barker (1992:1-43) to 
understand the relationship between under- and over-nutrition. It is argued that this relationship is responsible for the double burden of nutrition-related diseases presently experienced in South Africa. Thirdly, the policy implications of the link between poverty and malnutrition are discussed and recommendations are made for strategies to improve nutritional status as part of poverty-alleviation programmes.

\section{THE NUTRITIONAL STATUS OF SOUTH AFRICANS}

The main aim of this article is to argue for the inclusion of a nutritional intervention component in any programme aimed at poverty alleviation. To support this argument, the link between poverty and malnutrition, from a molecular to societal level, is explained in the next section. However, to design appropriate programmes, the nutritional component should be based on and be specific to the nutritional situation and needs in a specific country or setting. In this part of the article, the nutritional situation and problems in South Africa are therefore briefly reviewed.

South Africa is a multicultural, multi-ethnic country in which a major part of the population is in a process of transition from traditional rural lifestyles to urban, more 'Westernised' modern lifestyles. This transition is accompanied by a 'nutrition transition' (Vorster 2001:239-243) characterised by changes in dietary patterns, nutrient intakes, physical activity levels, consumption patterns of alcoholic beverages, as well as changes in socioeconomic and education status. These changes are interrelated and impact directly or indirectly on nutritional status. They are partly responsible for differences in nutrition and health status between rural and urban South Africans as well as changes in the whole population over time. The situation is worsened by the present economic crisis and increased food prices: 'the poor are facing higher food prices but no greater income, and begin to starve' (Sen 2008).

In the absence of a national surveillance system to monitor nutritional status, the Department of Health (Directorate Nutrition), the Medical Research Council (MRC), as well as the universities active in nutrition research, individually and often in partnership, have researched and reported on the nutrition situation in South Africa. Results of these studies have recently been reviewed by Steyn (2006), who reports similar results to those of an earlier review by Vorster et al. (1997), indicating that the nutritional status of South Africans has been far from optimal for many years. The most pressing nutrition-related public health problems have been confirmed by the most recent national study (Labadarios et al. 2008). These problems are briefly discussed here.

\section{Inequity between and within population groups}

The first problem is the unacceptable differences in undernutrition between rural and urban populations and between ethnic groups. Two examples, namely stunting in children and underweight in men, illustrate this statement.

Stunting or low height for age, indicative of chronic, long-term dietary inadequacy also reflecting socioeconomic deprivation, is mostly used as a measure of nutritional status in children (Vorster et al. 1997). A recent national study showed that 26.5\% of South African children in rural areas were stunted compared to $16.7 \%$ in urban areas (Labadarios et al. 2000).

The latest (1998) South African demographic and health survey indicated that while only $5 \%$ of white men were underweight with a body mass index (BMI) of less than $18.5 \mathrm{~kg} / \mathrm{m}^{2}, 12.1 \%$, $12.9 \%$ and $16.9 \%$ of coloured, black and Indian men respectively could be classified as being underweight (Puoane et al. 2002).

The relatively high prevalence of stunting in children and underweight in adult men indicates that despite the country being food and nutrition secure on a national level, even in a position to export some foods, many South Africans go hungry and are food insecure. As already mentioned, food security is defined as the human right to be able to access safe, affordable and sufficient food to be well-nourished and lead productive lives (Food and Agriculture Organization 1997, 2001a). Food insecurity exists when people are unsure where their next meal will be coming from. It is reasonable to suspect that most of the observed stunting and underweight in a country like South Africa would be the result of the inability of the poor to access enough nutritious food to meet their needs.

\section{The double burden of under- and over-nutrition}

The second problem is the co-existence of under- and overnutrition in the same household, family or community. This double burden is extended to a double burden of disease. South Africa has a high prevalence of both infectious diseases related to under-nutrition and of non-communicable diseases (NCDs) related to obesity and over-nutrition (Bradshaw et al. 2006). Therefore, as in many other developing countries (Standing Committee on Nutrition 2006), the over-nutritionrelated diseases emerged before the battle against undernutrition deficiency diseases has been won. This phenomenon can, at least partially, be explained by the effects of foetal malnutrition and the low quality of staple-food diets (sufficient energy but not enough micronutrients) in poor households. However, the relationship between household food insecurity and the overweight status of mothers and children are not only observed in developing countries. Several authors have found that this phenomenon is also prevalent in the developed world (Crawford et al. 2004; Townsend et al. 2001).

\section{Overweight and obesity}

The third problem is the rising tide of obesity. South Africa reflects the global trend of increased overweight and obesity in adults and children. Individuals with a BMI above $25 \mathrm{~kg} / \mathrm{m}^{2}$ are classified as being overweight, and those with a BMI above $30 \mathrm{~kg} / \mathrm{m}^{2}$ as obese. The 1998 demographic and health survey showed that $58.5 \%$ of black women and $54.5 \%$ of white men were either overweight or obese (Puoane et al. 2002). Combined with the figures for underweight, it seems that less than half of adult South Africans are maintaining normal body weight for height, reflecting imbalances in energy intake and expenditure. The national food consumption survey of 1999 (Labadarios et al. 2000 ) showed that approximately $6 \%$ of South African children were obese. Furthermore, the THUSABANA study (conducted during January 2000 - June 2001) (Kruger, Margetts \& Vorster 2004; Mukuddem-Petersen \& Kruger 2004) showed that stunting in girls, a consequence of chronic early malnutrition, may be involved in the development of later obesity among black South African women. Armstrong et al. (2006:439), who examined more than 10000 primary-school children, concluded that at the time of the survey (2001-2004), 'South African children show trends of obesity and overweight similar to values in developed countries about 10 years ago'.

Clearly, the double burden of under- and over-nutrition in South Africa as well as the rising tide of obesity despite the high prevalence of poverty indicates that new approaches are necessary to examine and address the poverty-nutrition relationship.

\section{Hidden hunger}

The fourth problem is that of 'hidden hunger', a term used to indicate micronutrient deficiencies in apparently well-fed individuals. Micronutrient deficiencies with distinctive clinical symptoms and often tragic consequences occur in many stunted and underweight individuals; however, this may also be prevalent in normal-weight, overweight and obese individuals. Exact figures are not known, but Steyn (2006) and Vorster et al. (1997) showed in their respective analyses of available dietary intake data that many South Africans do not meet their requirements for calcium and iron (especially black women and 
girls), zinc (most groups), riboflavin (most groups), vitamin B6 (most groups), folate (Indian and black women), vitamin C (Indian, coloured and black groups) and vitamin A (especially children). Micronutrient deficiencies in South Africa are being addressed by the mandatory fortification of table salt with iodine and maize meal and bread flour with a vitamin and mineral mix. This is a commendable scheme, based on an analysis of existing intakes and needs among South African children as indicated by the national food consumption survey (Labadarios et al. 2000). However, the impact of the staple-food fortification programme on the micronutrient status of the population remains to be measured.

\section{Negative effects of the nutrition transition}

The fifth problem is that at present, the nutrition transition referred to earlier is characterised by changes in dietary patterns that increase the risk of obesity and other NCDs. Intakes of animal-derived foods are increasing at the cost of plant-based foods (Bourne, Lambert \& Steyn 2002:157-162; Vorster 2002:239-243). While these changes improve calcium and iron intakes, they also increase saturated fat intake, one of the major risk factors for cardiovascular disease. The abundant availability of inexpensive oils leads to high intakes of total fat, another risk factor for becoming overweight, for obesity and many other NCDs (Steyn 2006). Clearly, the nutrition transition is contributing to the double burden of malnutrition, because previously undernourished populations in rural areas are exposed to diets in urban areas that are associated with an increased risk of NCDs.

As will now be discussed, the vicious cycle of the povertyrelated causes and consequences of malnutrition is illustrated in Figure 1. The figure was constructed from the evidence and information reported by the various authors cited in this section (Dao 2008; Engle \& Lhotska 1999; Grantham-McGregor, Fernald \& Sethuraman 1999; Institute for Fiscal Studies 2006; Nelson 2000; Streeten 1994; Wachs 1999). The cycle is 'vicious' because of reinforcing feedback where the consequences aggravate or exacerbate the causes of both poverty and malnutrition. The figure shows the different stages of the life cycle and how low birth-weight babies can become stunted children, adolescents and adults. These physically stunted individuals are often also mentally underdeveloped, with lower cognitive and noncognitive abilities and skills - a condition referred to as lower 'human capital'.

\section{THE VICIOUS CYCLE OF POVERTY AND MALNUTRITION}

\section{Nutrition and human development}

Human capital can be defined as well-nourished, healthy, educated, skilled and alert individuals - an improved human condition - resulting in a labour force that could be any country's most productive asset (Streeton 1994:232-237). Therefore, factors such as health, nutrition and formal education that an individual embodies and that provide future-returns are components of human capital (Dao 2008). The process of developing human capital begins early in infancy and continues throughout the life of the individual (Institute for Fiscal Studies 2006). Because this process is incremental in nature, early choices, inputs and events will have the power to either debilitate or facilitate development at more advanced stages (Institute for Fiscal Studies 2006). The figure further shows that reduced mental capacity and lower human capital development are results of foetal and early infant and childhood malnutrition because of malnourishment

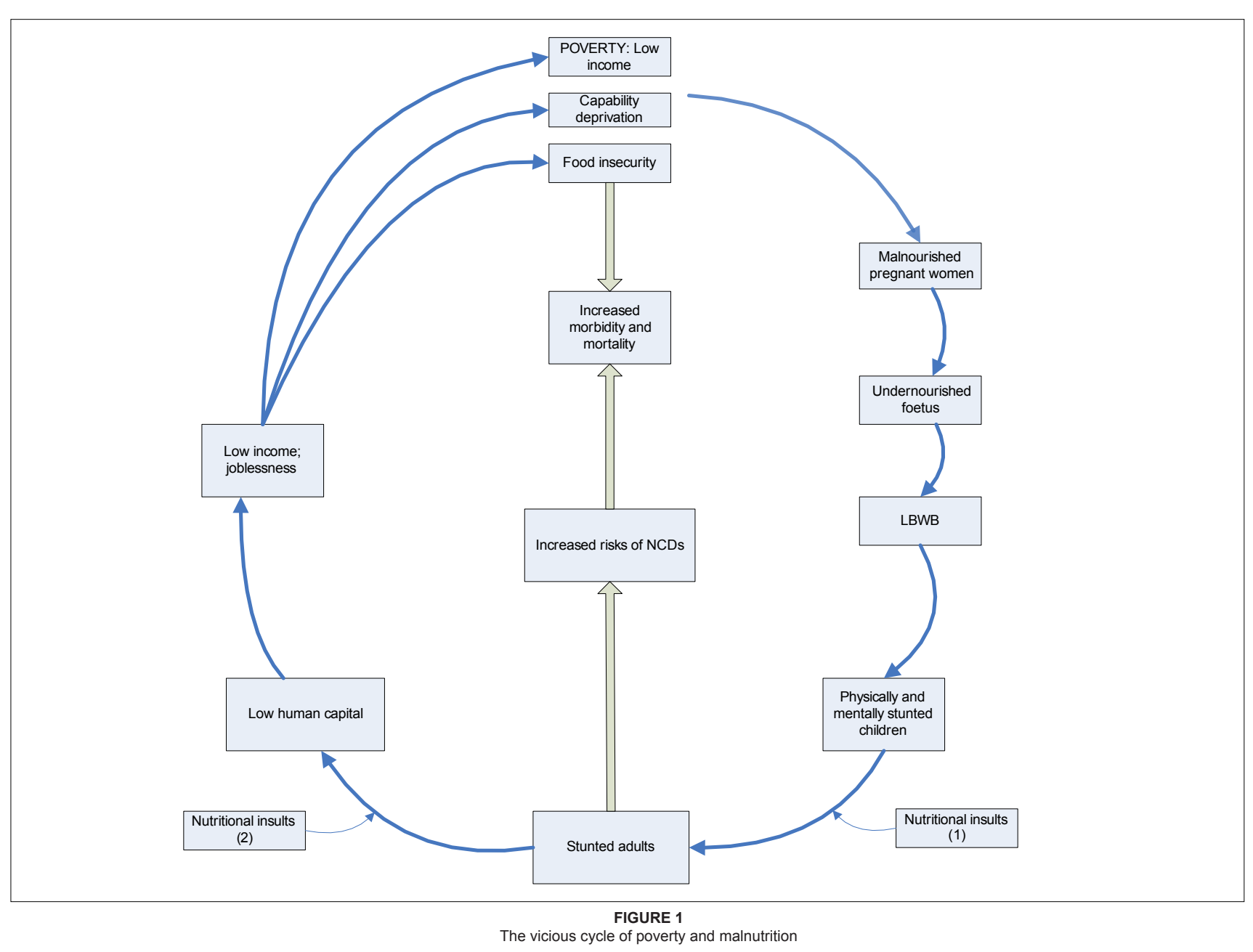


of pregnant women, as well as nutritional insults and other poverty-related causes during child development. The reduced human capital is associated with an inability to grow optimally, develop and benefit from education, poor socialisation and generally a reduced capacity to lead productive lives that will ensure food security and healthy environments for self and family.

The effects of under-nutrition on child development have been well researched and reviewed in both developed and developing world settings (Grantham-McGregor et al. 1999; Nelson 2000; Wachs 1999). Child development refers to more than only child morbidity and physical growth: it also includes behavioural developmental aspects that promote competence. The competent individual is one who can effectively adapt to and interact with his or her environment (Wachs 1999). According to Wachs (1999), traits defining individual competence fall into five domains, namely

- cognitive skills: skills related to intellectual activity such as thinking, reasoning, remembering, imagining or learning; characterised by alertness in infancy, intelligence and communication skills

- temperament/personality: characterised by high activity levels in infancy, self-regulation of attention and emotionality, showing of affection, sociability and an internal locus of control during childhood and adolescence

- motivation: reflected in the need for competence, the need for self-reliance during childhood and adolescence as well as achievement orientation during these periods

- self-perceptions: characterised by secure attachment during infancy, a sense of self-efficacy and positive self-concep during childhood and adolescence, as well as a sense of responsibility during adolescence

- interpersonal style: the ability to use adults as a resource and interpersonal sensitivity during adolescence.

These domains overlap and the expression of individual differences in competence is partially moderated by context, including genetic, nutritional, environmental and cultural contributions. Clearly, the development of competence in infants, children and adolescents is multi-determined and requires complex, integrated interventions (Engle \& Lhotska 1999; Nelson 2000). There is agreement among researchers working in the field of child development (Engle \& Lhotska 1999; Grantham McGregor et al. 1999; Nelson 2000; Wachs 1999) that nutritional and other interventions that address the poverty-related causes of under-nutrition will improve child development, especially if they are instituted in the first three years of life.

The difficulty of escaping the vicious cycle of poverty and malnutrition is illustrated by the fact that low education levels of parents limit their ability to promote good nutrition, development and health in their children. The resultant poor developmental and educational level of the malnourished child will limit economic productivity in later life, explaining the intergenerational effect of the vicious cycle.

\section{Foetal malnutrition}

Figure 1 illustrates that foetal nutrition is an important link between poverty and the development of human capital. It shows that low birth-weight babies (without catch-up growth because of a lack of appropriate interventions) will develop into stunted children and become adults with reduced human capital. But moreover, it is now recognised that foetal malnutrition also leads to disproportionate-sized babies that are programmed to have an increased risk of chronic NCDs in later life. These NCDs include obesity, insulin resistance, diabetes mellitus, hypertension and cardiovascular diseases such as coronary heart disease and stroke.

This 'early origins of adult disease' was first suspected when David Barker and his colleagues observed that areas in Britain with high rates of death from cardiovascular disease previously had high prevalence of infant mortality (Barker 1992). Meticulous studies on individuals suffering from different NCDs eventually led to the formulation of the Barker hypothesis that 'undernutrition in utero permanently changes the body's structure and function in ways that programme the appearance of disease in later life' (Barker 1997). Understandably, it would be difficult to prove this hypothesis in retrospective studies, especially in developing countries where birth data of adults suffering from NCDs are scarce, inaccurate or non-existent. However, Levitt, Lambert and Norris (2006) reviewed data from several South African studies and showed a definite link between undernutrition and stunting in African children and adolescents with a propensity to obesity.

Rajagopolan (2003) reviewed the evidence that maternal malnutrition will adversely influence the foetus, leading to compromised growth and a changed body composition (percentage of muscle mass), changed brain development and altered metabolic programming of glucose and lipid metabolism, as well as hormone, receptor and gene functions in the short term. According to the Barker hypothesis, supported by evidence from developed and developing countries, in the long term these changes will lead to reduced cognitive development, decreased educational performance, compromised immunity, lower work capacity and an increased risk of many NCDs (Rajagopolan 2003).

There is a growing understanding of the possible underlying mechanisms responsible for the link between foetal malnutrition and risk of NCDs in later life. There is evidence that malnutrition may influence genetic expression via epigenetic modification of DNA methylation in foetal life (Gluckman, Hanson \& Pinal 2005). It is hypothesised that the changed genetic expression may change physiological set points that will eventually change the way individuals respond to environmental exposures in later life.

Despite these advances in the understanding of the phenomenon of the early origin of disease, much more research is needed on the programming of the various neurological and endocrine regulatory potential during foetal life. In addition, more knowledge is needed about the optimal nutrition for pregnant women, optimum growth in childhood and influences of psychosocial and cultural environments in order to design optimal interventions that will minimise NCD risk in adult life. At this point in time, available data show that women of child-bearing age should be well nourished, empowered and educated. Solomons (2005:212) mentions that they are the most 'proximal levers' to effect beneficial practices and attitudes in the home to ensure optimal foetal, infant and childhood nutrition.

\section{The impact of HIV/AIDS on the vicious cycle}

The HIV/AIDS epidemic in South Africa has profound effects on nutritional status, food security and the vulnerability of affected individuals and families (Vorster 2007). In addition to the direct effect of the $\mathrm{HI}$ virus on nutritional status, the socioeconomic consequences of HIV / AIDS are devastating, as it promotes the vicious cycle of poverty and malnutrition. Because it is mainly a sexually transmitted disease in economically active young to middle-aged adults, it turns uneducated children into breadwinners and grandparents into child carers. Infection with the virus is associated with increased nutritional needs, but, at the same time, with lower intakes and decreased absorption of nutrients (Vorster 2007), resulting in the characteristic wasting (weight loss) of infected people, which gave origin to the description of AIDS as the 'slim disease'.

It is suspected that the vicious relationship between malnutrition and poverty, which results in compromised immunity, increases the risk of transmission of the HI virus through biological and behavioural mechanisms. It is also suspected that malnutrition in infected people will accelerate the progression of HIV to AIDS (World Health Organization 2005). The burden of HIV/ 
AIDS on the health budget and resources in South Africa is not the topic of this article. However, it should be kept in mind that HIV/AIDS has a negative effect on the already compromised nutritional status of many South Africans, and that it contributes directly and indirectly to the poverty-malnutrition cycle.

\section{DISCUSSION}

The double burden of nutrition-related disease in South Africa, and what is known about the vicious cycle of poverty and malnutrition, argue for an inclusion of nutrition interventions in poverty-alleviation programmes. From historical (Horrell, Humphries \& Voth 2001) and also present analyses of data from the developing world (Dao 2008) it is clear that only an improvement in human capital through interventions in health, nutrition and education will lead to increased productivity and hence income to lift individuals out of poverty.

The question that needs urgent attention, therefore, is: when, where and how should interventions to improve nutrition be included and integrated into policies that address poverty? The literature abounds with examples of strategies and programmes to improve nutritional status (Food and Agriculture Organization 2005; Kiess, Moencl-Pfanner \& Bloem 2001; World Health Organization 2006). The challenge is to integrate these food and nutrition interventions into poverty-alleviation efforts. Because poverty is both a cause and a consequence of malnutrition, any intervention should allow individuals, families and communities to escape the vicious poverty-malnutrition cycle. This will only be possible if programmes simultaneously address all the immediate, underlying and basic causes of malnutrition in holistic, but integrated, multisectoral, multidisciplinary interventions that are target- and country-specific (based on existing situations). There seems to be consensus in the nutrition literature that these programmes should target women and children, with a specific focus on pregnant women (Solomons 2005). Furthermore, it is mandatory that food aid should not be given in isolation: It should be accompanied by education, better health care and the creation of opportunities for income generation. In other words: empowerment of the poor.

Solomons (2005) suggests seven guidelines for policy and programme transition to alleviate NCD risk. These guidelines are also relevant for the planning of poverty-alleviation programmes with a nutrition intervention component. They are especially relevant for developing countries such as South Africa, where chronic NCDs have emerged before under-nutrition has been eradicated in the economically deprived sections of the population. The guidelines are given in abbreviated form:

- (Re)educate and sensitise the leadership and authorities at all policy levels with the evidence base for the role of earlylife nutritional strategies. This must be done in harmony with (and not as counterpoint to) the established concerns for food insecurity and micronutrient malnutrition.

- Move from the exclusive 'Ministry of Health obsession' to a broader multisectoral coalition strategy that includes the governmental sectors of Agriculture, Trade and Commerce, Economy, Finances, Education, Culture and Recreation as well as the stakeholders in the private sector and civil society.

- Avoid the temptation for 'magic bullets' and 'one-size-fitsall' universal solutions promulgated by the international (multilateral and bilateral) agencies and interests and locally individualise the formulas for changes in policies and programme efforts toward reducing chronic disease in later life.

- Prioritise the most inexpensive-to-mount and/or the most cost-effective programmes initially in order to avoid 'sticker shock' for the constrained operating budgets of developing countries.

- Exercise careful deliberations regarding the policy choices between universal, mass interventions (with the adverse consequences of creating entitlements for individuals neither at risk nor in the line of benefits) versus selectively targeted interventions (with their dual drawbacks of stigmatisation and perception of discrimination)

- Continue to emphasise (and at the same time redirect) the education and empowerment of women in developing countries as the most proximal lever for effecting beneficial practices and attitudes in the home. This is preconditioned by campaigns to bring women to full literacy and scholastic parity with men, and assuring their economic rights within the household.

- All that is simple is not safe. Emphasise and integrate a concern for 'safety testing' of interventions in both the short term of efficacy trials and in long-term monitoring. The same measures may have benefits and risks but with different time courses, with the benefits emerging early and the adverse effects manifesting later.

The Solomons guidelines given above are aimed at promoting policy with the aim of breaking the poverty-malnutrition cycle. Much has been done during the last 15 years to improve the nutritional status of South Africans by the Department of Health, by targeting vulnerable groups with an integrated nutrition policy (Faber \& Wenhold 2007; Labadarios et al. 2005). However, as pointed out by Steyn and Labadarios (2003), a lack of resources is a significant barrier to the successful implementation of this policy. As mentioned above, the Solomons guidelines can be used in the application of existing nutrition policy, but moreover, they should be applied to incorporate a nutrition intervention component into poverty-alleviation programmes.

\section{CONCLUSION}

The Solomons guidelines are the first steps in the planning of programmes that will address the long-term consequences of foetal malnutrition. Because they emphasise the importance of targeting women in their productive years, they will also help to address the short-term consequences of foetal malnutrition. The way women in their productive years are targeted will differ from country to country, depending on the local situation. For example, it could be possible to access these women in secondary schools (as the mothers of tomorrow) through a school feeding programme. This is one way of breaking the vicious povertymalnutrition cycle and preventing the hopelessness and despair associated with poverty from being carried over from generation to generation. The nutrition of the foetus could also be improved by ensuring that all pregnant women attending antenatal clinics are supplemented with micronutrients (in the form of supplements or fortified foods). Despite excellent policies in this regard in South Africa, many pregnant women may be enrolled at antenatal clinics too late for the foetus to benefit from this supplementation. Improved nutrition of the foetus supported by appropriate interventions throughout the life cycle will help to prevent stunting in children, adolescents and adults, resulting in improved mental development and increased human capital, increased production and eventually in income and an escape from poverty. There is hope-but it will require concerted efforts from committed partnerships between all involved stakeholders to plan and implement holistic programmes that integrate nutrition interventions into programmes for poverty alleviation.

\section{ACKNOWLEDGEMENTS}

The financial support of SANPAD (South African Netherlands Programme for Alternatives in Development) for this research project and paper is acknowledged.

\section{REFERENCES}

Armstrong, M.E.G., Lambert, M.I., Sharwood, K.A. \& Lambert, E.V., 2006, 'Obesity and overweight in South African primary school children - the Health of the Nation Study', South African Medical Journal 96(5), 439-444. 
Barker, D.J.P. (ed.), 1992, Fetal and infant origins of adult disease, British Medical Journal, London.

Barker, D.J.P., 1997, 'Prenatal influences on disease in later life', in P.S. Shetty \& K. McPherson (eds.), Diet, nutrition and chronic disease: Lessons from contrasting worlds, pp. 41-58, Wiley, Chichester.

Berg, A., 1973, The nutrition factor: Its role in national development, The Brookings Institution, Washington.

Bourne, L.T., Lambert, E.V. \& Steyn, K., 2002, 'Where does the black population of South Africa stand on the nutrition transition?', Public Health Nutrition 5(1), 157-162.

Bradshaw, D., Schneider, M., Norman, R. \& Bourne, L.T., 2006, 'Mortality patterns of chronic diseases of lifestyle in South Africa', in K. Steyn, J. Fourie \& N. Temple (eds.) Chronic diseases of lifestyle in South Africa, pp. 58-64, Medical Research Council, Tygerberg.

Crawford, P.B., Townsend, M.S., Metz, D.I., Smith, D., EspinosaHall, G., Donohue, S.S. et al., 2004, 'How can Californians be overweight and hungry?', California Agriculture 58(1), 12-17.

Dao, M.Q., 2008, 'Human capital, poverty, and income distribution in developing countries, Journal of Economic Studies 35(4), 294-303.

Engle, P.L. \& Lhotska, L., 1999, 'The role of care in programmatic actions for nutrition: Designing programmes involving care', Food and Nutrition Bulletin 20(1), 121-135.

Faber, M. \& Wenhold, F., 2007, 'Nutrition in contemporary South Africa', Water SA 33(3), 390-398.

Food and Agriculture Organization, 1997, Agriculture, food and nutrition for Africa, Rome.

Food and Agriculture Organization, 2001a, Food insecurity: When people live with hunger and fear starvation, Rome.

Food and Agriculture Organization, 2001b, Millennium Development Goal No. 1, viewed 28 December 2006, from http://www.fao.org/docrep/008/a0056e/A0056E04.html

Food and Agriculture Organization, 2005, The state of food insecurity in the world, Pamphlet AD/I/A0199E/1/11.05/700, Rome.

Garza, C., 2002, 'The nutrition situation: An overview', Food and Nutrition Bulletin 23(4), 343-344.

Gluckman, P.D., Hanson, M.A. \& Pinal, C., 2005, 'The developmental origins of adult disease', Maternal and Child Nutrition 1(3), 130-141.

Grantham-McGregor, S.M., Fernald, L.C. \& Sethuraman, K. 1999, 'Effects of health and nutrition on cognitive and behavioural development in children in the first three years of life. Part 1: Low birth-weight, breastfeeding and proteinenergy malnutrition. Part 2: Infections and micronutrient deficiencies: Iodine, iron and zinc', Food and Nutrition Bulletin 20(1), 53-99.

Horrell, S., Humphries, J. \& Voth, H.J., 2001, 'Destined for deprivation: Human capital formation and intergenerational poverty in nineteenth-century England,' Explorations in Economic History 38(3), 339-365.

Institute for Fiscal Studies, 2006, Human development and poverty reduction in developing countries, viewed 28 December 2006 from www.ips.org.uk

Kiess, L., Moench-Pfanner, R. \& Bloem, M., 2001, 'Foodbased strategies: Can they play a role in international development?', Food and Nutrition Bulletin 22(4), 436-442.

Kruger, H.S., Margetts, B.M. \& Vorster, H.H., 2004, 'Evidence for relatively greater subcutaneous fat deposition in stunted girls in the North-West province, South Africa, as compared with non-stunted girls', Nutrition 20, 564-569.

Labadarios, D., Steyn, N., Maunder, E., MacIntyre, U., Swart, R., Gericke, G. et al., 2000, The National Food Consumption Study (NFCS) in children aged 1-9 years, South Africa, Department of Health, Pretoria.

Labadarios, D., Steyn, N., Mgijima, C. \& Dladla, N., 2005, 'Review of South African nutrition policy 1994-2002 and targets for 2007', Nutrition 21(1), 100-108.

Labadarios, D., Swart, R., Maunder, E.M.W., Kruger, H.S Gericke, G.J., Kuzwayo, P.M.N. et. al., 2008, 'Executive summary of the National Food Consumption Survey: Fortification baseline (NFCS-FB-1)', South African Journal of Clinical Nutrition 21(3) (suppl. 2), 247-300.
Levitt, N.S., Lambert, E.V. \& Norris, S.A., 2006, 'Early life origins of adult chronic diseases: A South African perspective', in N. Steyn, J. Fourie \& N. Temple (eds.), Chronic diseases of lifestyle in South Africa, pp. 58-64, Medical Research Council, Tygerberg.

Mukuddem-Petersen, J. \& Kruger, H.S., 2004, 'Association between stunting and overweight among 10-15 year old children in the North-West province of South Africa: The THUSABANA study', International Journal of Obesity 28 , 842-851.

Nelson, M., 2000, 'Childhood nutrition and poverty', Proceedings of the Nutrition Society 59(2), 307-319.

Puoane, T., Steyn, K., Bradshaw, D., Laubscher, R., Fourie, J., Lambert, V. et al., 2002, 'Obesity in South Africa: The South African demographic and health survey', Obesity Research 10, 1038-1048.

Rajagopolan, S., 2003, 'Nutrition challenges in the next decade', Food and Nutrition Bulletin 24(3), 275-280.

Sen, A., 1998, 'The possibility of social choice', Nobel lecture, Economic Sciences 190, 178-225.

Sen, A., 2008, 'The rich get hungrier', The New York Times, 28 May, [no access date] from http://www.nytimes. com/2008/05/28/opinion/28sen.html?_r=1

Solomons, N.W., 2005, ‘Programme and policy issues related to promote positive early nutritional influences to preven obesity, diabetes and cardiovascular disease in later life: A developing countries view', Maternal and Child Nutrition 1(3), 204-215.

Standing Committee on Nutrition, 2006, 'Diet-related chronic diseases and the double burden of malnutrition in West Africa', SCN News 33, 1-78.

Steyn, N.P., 2006, 'Nutrition and chronic diseases of lifestyle in South Africa', in K. Steyn, J. Fourie, N. Temple (eds.) Chronic diseases of lifestyle in South Africa, pp. 58-64, Medical Research Council, Tygerberg.

Steyn, N.P. \& Labadarios, D., 2008, 'Understanding the determinants of obesity', South African Journal of Clinical Nutrition 21(4), 304-305.

Steyn, N. \& Labadarios, D., 2002, 'Review of nutrition policy implementation', South African Health Review, viewed n.d., May 2010, from http://www.hst.org/za/uploads/files/chapter 17.pdf

Streeten, P., 1994, 'Human development: Means and ends', American Economic Review 84(2), 232-237.

Townsend, M.S., Love, B., Achterberg, C. \& Murphy, S., 2001, 'Food insecurity is positively related to overweight in women', Journal of Nutrition 13, 1738-1745.

UNICEF, 1990, Strategy for improved nutrition of children and women in developing countries, policy review paper, E/ ICEF/1990/1.6, New York.

Vorster, H.H., 2001, 'The emergence of cardiovascular disease during urbanisation of Africans', Public Health Nutrition 5(1), 239-243.

Vorster, H.H., 2007, 'Nutrition and HIV and AIDS', in J. Mann \& S. Truswell (eds.), Essentials of human nutrition, pp. 558-569, Oxford University Press, Oxford.

Vorster, H.H., Oosthuizen, W., Jerling, J.C., Veldman, F.J. \& Burger, H.M., 1997, 'The nutritional status of South Africans: A review of the literature from 1975-1996', Durban: Health Systems Trust (1), 1-22, (2), 1-122.

Wachs, T.D., 1999, 'The nature and nurture of child development', Food and Nutrition Bulletin 20(1), 7-22.

World Health Organization, 2005, Consultation on nutrition and HIV/AIDS in Africa: Evidence, lessons and recommendations for action, Durban, South Africa 10-13 April 2005, Geneve.

World Health Organization, 2006, 'Integrated intersectoral food and nutrition policies and strategies to address the double-burden of nutrition problems throughout the life course', Regional/sub-regional capacity-building training workshop, Johannesburg, January. 